\title{
EFFECT OF DIETARY NIACIN AND/OR THIAMIN SUPPLEMENTATIONS ON GROWTH AND FATTENING PERFORMANCE OF BUFFALO CALVES.
}

\author{
Ebtehag, I. M. Abou-Elenin; A. A. Abdou; W. A. Riad and M. R. M. Mostafa \\ Animal Production Research Institute, ARC, Giza, Egypt.
}

(Received 18/10/2016, Accepted 22/11/2016)

\section{SUMMARY}

$\mathrm{T}$

This study was conducted to evaluate the effect of feeding supplemented diets by ether niacin, thiamin or its mixture on the growth and fattening performance of buffalo calves. A feeding trial was carried out using twenty growing buffalo calves with average initial weight $275 \pm 2.6 \mathrm{Kg}$ and aged 14 months. They were divided into four similar groups ( 5 calves each) in 120 - day feeding trial periods using the randomized complete block design. All animals' groups were fed individually along the experimental period on a basal ration (BR) that consisted of $69.5 \%$ concentrate feed mixture (CFM), $17.4 \%$ rice straw (RS) and $13.1 \%$ corn silage (CS) on DM basis. A certain amounts of dietary niacin and/or thiamin were mixed thoroughly with $\mathrm{CFM}$ as in the following treatments. Animals were given BR without supplements $\left(\mathrm{T}_{1}\right)$ as control, BR supplemented with $0.5 \mathrm{~g}$ niacin/head/day $\left(\mathrm{T}_{2}\right)$, BR plus $0.5 \mathrm{~g}$ thiamin/h/d $\left(\mathrm{T}_{3}\right)$ and BR supplemented with $0.25 \mathrm{~g}$ niacin and $0.25 \mathrm{~g}$ thiamin/ $/ \mathrm{d}\left(\mathrm{T}_{4}\right)$. Animals were fed according to allowances of kearl (1982) for buffalo calves. Four digestibility trials were conducted to determine the digestibility and feeding values of the experimental rations. Results indicated that digestibility of DM and OM were insignificantly increased with $T_{2}$ and $T_{3}$ rations, but significantly $(p<0.05)$ increased with $T_{4}$ one, compared with control $\left(\mathrm{T}_{1}\right)$. Digestibility of $\mathrm{CF}$, EE and NFE followed the same trend of DM among treatments. Otherwise, CP digestibility was slightly improved with all tested rations. The values of TDN, DCP and DE were followed similar trends to that of nutrients digestibility among treatments. Daily feed intake wasn't affected significantly by the two supplements. Total weight gain and daily gain were significantly $(\mathrm{p}<0.05)$ higher in all tested rations in comparison of control one, while the highest value had occurred with $\mathrm{T}_{4}$. Regarding feed conversion measurement, significant improvement due to both supplements and its mixture were found respecting DM,TDN or DCP: gain, compared with unsupplemented diet (control). Concerning economic evaluation, net revenue and economical efficiency were markedly increased with supplemented rations compared with control one. No significant differences were found among treatments in blood total protein and creatinine. It could be concluded that either niacin or thiamin and its mixture had an effectiveness role for improving the performance of fattening buffalo calves when the concentrate feed mixture was high percentage in their rations.

Keywords: Niacin, thiamin, ruminants feeding, supplement, fattening calves.

\section{INTRODUCTION}

During the last decade and due to the pressure of high population worldly, an intensive livestock production systems are becoming urgently use to secure the huge food demands for such highly growing world's population. Such great intensification system needs significant changes in feeding systems and formulation the rations for cattle than the traditional ones. For instance, increasing the concentrate portion in the rations on the expense of roughage one that causing a negative effect on rumen functions and in turn the productive performance of animals. So, under these intensive farming systems, potentially must be using the technology of supplementing the feed additives to correct and monitoring any deviation than nature and in turn outputted the full potential of genetically productive performance. A massive efforts are currently on the race to evaluate a huge types of additives in order to guarantee its potential benefits when incorporated in animals' rations and consequently increasing the production of farm animals. There are an accession of varieties of feed additive and accurately must be choose the most suitable and effective one for a certain ration formulation. Specifically, changes in the roughage to concentrate ratio of 
the diet are known to alter the microbial activities in the rumen (Girard et al., 1994). In consistent, Santschi et al. (2005) revealed that ruminal B-vitamin concentrations can be altered by dietary manipulation, changes in forage to concentrate ratio, composition of the diet and the dynamic environment of the rumen due to the continuous flow of the digesta into the lower gut. Earlier research findings demonstrated that microbial production of niacin in the rumen does not meet the requirements of growing calves (Girard, 1998) and oral administration of niacin has resulted to increase microbial protein synthesis (Shields et al., 1983 and Flachowsky, 1993) and VFA's (Doreau and Ottou, 1996 and Ottou and Doreau, 1996). Feasibly, Kumar and Dass (2005) concluded that supplementation of niacin into the diet of buffaloes had improved the rumen functions by decreasing the ammonia-N concentration and therefore increasing protein synthesis. In addition, Flachowsky (1993) indicated that beef cattle appeared to be in modulator effect as niacin supplemented at $1 \mathrm{~g} / \mathrm{h} / \mathrm{d}$ or approximately $100 \mathrm{mg} / \mathrm{kg}$ DMI, when body weight of bulls is lower than $300 \mathrm{~kg}$ and the diet are poor in protein content (10 to 12\%) CP of DM and also during dietary adaptation period. Regarding ruminal thiamin concentration, it is a result of thiamin synthesis and degradation by ruminal microorganisms (Harmeyer and KallenKirchen, 1985). Both rumen conditions and the activity of rumen microorganisms are largely affected by feeding conditions particularly intake level, concentrate feed level, roughage quality, nutrients balance...etc. A sudden drop in ruminal $\mathrm{pH}$ can induce increased thiaminase activity which can destroy the thiamin and attained thiamin deficiency (Zinn et al., 1987). In Egypt, Kholif et al. (2009) observed that supplementation of $340 \mathrm{mg}$ thiamin/cow/day to their rations increased milk yield by $13 \%$ and milk protein by $16 \%$ in comparison with control ration that free from the supplement. Comparable results in which $40 \mathrm{mg} / \mathrm{h} / \mathrm{d}$ thiamin supplemented into the diet of ewes, were recognized by Solouma et al. (2013). It was improved blood metabolites and in turn significantly increased milk yield and milk composition as well as reduced somatic cell count in ewe's milk. Moreover, positive significant effect on growth performance was found by El-Shanti et al. (2012) due to including 20 or $40 \mathrm{mg} / \mathrm{h} / \mathrm{d}$ thiamin in diets of Assaf lambs. Finally, Mostafa et al. (2015) concluded that using either thiamin or niacin supplementations into rations of growing and fattening Friesian calves tended to improve productive performance and economical efficiency for fattening calves, with the best results are associated with niacin supplement. So far, the literature presents somewhat conflicting results about the effects of ration's formulation and composition on ruminal B-vitamin fractions concentrations.

The present study was carried out to evaluate the effect of either niacin and/or thiamin on growthfattening performance of buffaloes calves.

\section{MATERIALS AND METHODS}

This research work was conducted in animal production research institute, ARC, Ministry of agriculture, in cooperation with Messier buffalos production farm that belonging to the production sector, ARC, Ministry of agriculture, Kafr El-Shiekh governorate, Egypt. Twenty buffalo calves with average age were 14 months and $275 \pm 2.6 \mathrm{~kg}$ live body weight were divided into four similar groups $(5$ calves each) in feeding trial using a complete randomized block design. All animals' groups were fed individually for about 120-days experimental period on a basal ration (BR) that consisted of $69.5 \%$ concentrate feed mixture (CFM), $17.4 \%$ rice straw (RS) and $13.1 \%$ corn silage (CS) on dry matter basis. Supplementation of niacin and/or thiamin were mixed thoroughly with CFM and offered to animals as in the following dietary treatments: $\mathrm{T}_{1}$ fed the basal ration (BR) without supplementation (as control), $\mathrm{T}_{2}$ fed BR with $0.5 \mathrm{~g}$ niacin $/ \mathrm{h} / \mathrm{d}, \mathrm{T}_{3}$ fed BR with $0.5 \mathrm{~g} / \mathrm{h} / \mathrm{d}$ thiamin and $\mathrm{T}_{4}$ fed BR plus $0.25 \mathrm{~g} / \mathrm{h} / \mathrm{d}$ niacin and 0.25 $\mathrm{g} / \mathrm{h} / \mathrm{d}$ thiamin. The CFM used in this experiment was consisted of corn grain $36 \%$, barley grain $20 \%$, wheat bran $25.6 \%$, soybean meal $15 \%$, limestone $2 \%$, common salt $1 \%$, mineral $0.4 \%$. Animals were fed according to allowances of Kearl (1982) for buffalo calves twice daily at 8 am and $4 \mathrm{pm}$. Fresh water was free along the day round. All animals were vaccinated and treated in accordance of the established routine of the feedlot and they injected with vitamins $\mathrm{AD}_{3} \mathrm{E}$ to cover their requirements. Post overnight withdrawal period of feed and water, shrunk weights for experimental animals were recorded for two successive days at the beginning and the end of the trial and every two weeks in between as well. Four digestibility trials were conducted simultaneously on the animals of the feeding trial (three animals from each group) to determine the nutrients digestibility and feeding values of the experimental rations. Acid Insoluble Ash (AIA) method was applied as an internal marker as described by Van Keulen and Young (1977). Fecal grab samples of nearly $200 \mathrm{gm}$ were taken from the rectum of each animal for 7- d collection period. Representative samples of feed and feces were taken for proximate analysis according to (A.O.A.C, 1995). Blood samples were taken from jugular vein into centrifuging tubes containing anticoagulant (EDTA) from three calves of each group at $3 \mathrm{hrs}$ after feeding. Blood samples were 
immediately centrifuged at $4000 \mathrm{pm}$ for 20 minutes to get blood plasma. The plasma total protein (TP) and albumin were determined according to Peters (1968) and Doumas (1971), respectively. Globulin was estimated by difference. Liver functions were assessed by measuring the activity of transaminases (AST and ALT) according to Reitman and Frankel (1957) and creatinine was measured according to Bartel (1971). Economical efficiency was expressed as the ratio between the price of output (weight gain) and the input cost (feed consumed) and also as feed cost/gain, was estimated based on the current price (LE/ton) being 2800, 400 and 300 for CFM, CS and RS, respectively. Thiamin was priced as $180 \mathrm{LE} / \mathrm{kg}$ and niacin $80 \mathrm{LE} / \mathrm{kg}$. The price of live body weight was $35 \mathrm{LE} / \mathrm{kg}$.

Data were statistically analyzed according to Snedecor and Cochran (1980) using general linear model program of SAS (1999). Duncan's multiple range test was employed to test for significant differences (Duncan, 1955).

\section{RESULTS AND DISCUSSION}

\section{Chemical composition}

The concentrate feed mixture used in this experiment was consisted of 36\% corn grain, $20 \%$ barley grain, $25.6 \%$ wheat bran, $15 \%$ soybean meal, $2 \%$ limestone, $1 \%$ common salt and 0.4 mineral salts and this formula being have $15 \% \mathrm{CP}$ and $71 \%$ as TDN, on DM basis. The chemical composition of experimental basal ration and its component are presented in Table (1).

Table (1): Chemical composition of feed ingredients and calculated chemical composition of basal ration (\% on DM basis).

\begin{tabular}{lcccc}
\hline & \multicolumn{4}{c}{ Chemical analysis (\%) } \\
\cline { 2 - 5 } Item & \multirow{2}{*}{ Concentrate } & Corn* & Rice & Basal \\
& Silage & Straw & Ration \\
\hline Dry matter (DM) & 91.30 & 27.10 & 94.12 & 85.01 \\
Organic matter (OM) & 91.64 & 92.66 & 87.94 & 91.07 \\
Crude protein (CP) & 14.81 & 8.6 & 4.31 & 12.23 \\
Crude Fiber (CF) & 11.99 & 27.51 & 31.07 & 17.13 \\
Ether extract (EE) & 2.6 & 2.01 & 1.56 & 2.35 \\
Ash & 8.36 & 7.34 & 12.06 & 8.93 \\
NFE & 62.24 & 54.54 & 51.00 & 59.36
\end{tabular}

*Fermentation properties were $\mathrm{pH}(4.01)$, lactic acid (4.22\% of DM), TVFA's (2.12\% of DM) and ammonia-N $5.11 \%$ of total $N$.

The proximate analysis of either CS or RS used in this study were extremely comparable to those recorded in the literature. The values of CP (14.81\%), CF (11.99\%) and EE (2.6\%) of CFM were also within the normal range of the currently manufactured concentrates in Egypt, that usually used for beef production. These values are close to those decided by RCFF (2001), being 14\% CP, 15\% CF and 65\% TDN values for finishing phase of beef cattle. The visual and chemical characteristics of corn silage are indicating to be obtained very good silage in its fermentative process being $\mathrm{pH} 4.01$, lactic acid $4.22 \%$ of DM, TVFA's $2.12 \%$ of DM) and ammonia-N $5.11 \%$ of total $\mathrm{N}$.

\section{Nutrients digestibility and feeding values:}

Results of digestion coefficients and feeding values of the experimental rations are presented in Table (2). Based on control, digestibility of DM, OM, CF, EE and NFE were insignificantly increased with rations $\mathrm{T} 2$ and $\mathrm{T} 3$, but significantly $(\mathrm{p}<0.05)$ increased with $\mathrm{T} 4$ (together supplements). While digestibility of $\mathrm{CP}$ was not significantly affected by dietary supplementation of niacin, thiamin and its mixture however, somewhat an improvement on digestibility of CP was happened with all tested rations compared with control one. Such improvement in digestibility might be attributes to the mutual positive effect of both supplements (thiamin \& niacin) on the vitality of rumen microorganisms and its 
proliferation which consequently arising the feed degradation efficiency. In ruminants, niacin is synthesized by rumen microorganisms and its synthesis has been considered to be adequate for their optimum performance (Hungate, 1966). Also, Schwab et al. (2006) concluded that B-vitamin intake, duodenal flow and ruminal synthesis are influenced by dietary forage and NFC contents. The feeding values which expressed as TDN, DCP and DE were followed the same trends of DM digestibility among treatments, with the highest values occurred with T4. In perspective, the modulatory effect of supplementation of niacin and/or thiamin into the diets of cattle greatly dependent on dietary factors and consequently the rumen condition that continuously seem to be in highly dynamic state. In relation to this point, Shaver and Bal (2000) suggested that a possible role for thiamin supplementation when dietary contents of NDF and ADF are lower and non-fiber carbohydrate is higher than recommended. In the meantime, Kumar and Dass (2005) reported that niacin supplementation in diet of buffaloes improved the rumen fermentation by decreasing ammonia- $\mathrm{N}$ concentration and increasing protein synthesis. The present results are in harmony with the findings obtained by Gabr et al. (2004) who found a markedly improvement in TDN and DCP values when supplemented sheep's diet with yeast culture (good source of vit. B complex). Definitely, Dawson (1994) found that yeast or yeast culture are rich source of vitamins, enzymes and others important and vital nutrients and act as co-factor which make them attractive as digestive enhancers of basic source of nutrients. Recently, Mostafa et al. (2015) proved that each of thiamin or niacin supplements tended to increased digestibility coefficients when they were incorporated in the diets of Friesian calves.

Table (2): Nutrients digestibility and feeding values of fattening buffalo calves fed experimental rations.

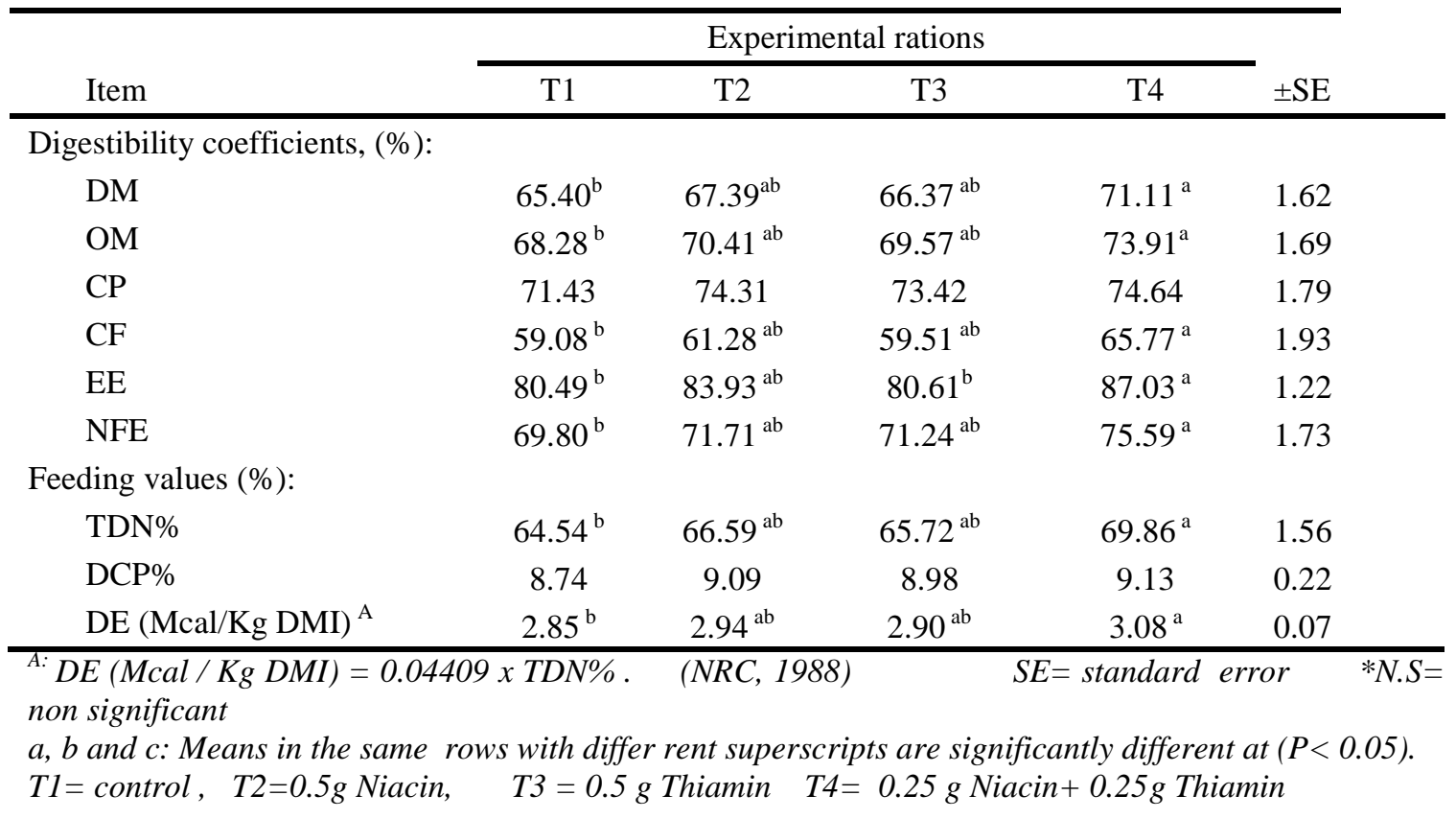

\section{Growth performance:}

Data of daily feed intake, total live body gain, daily gain and feed conversion ratio of calves fed the experimental rations are presented in Table (3).

\section{Daily feed intake:}

Daily feed intake that expressed as DM, TDN, DCP and DE were not significant affected by the dietary treatments. The lack of the effect of dietary treatments on feed intake might be due to so far the quality of the palatability of the experimented rations in which the addition of the two supplements have nothing effect on it. Likewise, mostly the digestibility of most nutrients particularly CP did not affected by the tested treatments that considered also as an another reason for the scanty differences among 
treatments in respect of feed intake. In consistent with this point, Miller (2002) indicated that sufficient nitrogen and rumen degradable protein must be supplied to maximize bacterial fermentation, energy digestibility and feed intake. In pertinence, digestion of fibrous feeds, which in turn increasing DMI, also increased by the provision of performed dietary protein (Carro and Miller, 1999). Conclusively, Nocek and Russell (1988) suggested that stimulating effect involves a cycle of improved efficiency of microbial protein synthesis, increased DM digestibility and thereby increased feed intake. Results here are in harmony with those reported by Kamalamma et al. (1996) and El-Shanti et al. (2012) who did not observed any effect of yeast culture or thiamin supplementation on DM, with cows and sheep, respectively. While, Erasmus et al. (1992) and Wang et al. (2001) found that an increase in DMI with yeast culture supplementations with diary cows' rations. Additionally, Mostafa et al. (2015) demonstrate that DM was significant increased due to supplement the rations of fattening Friesian calves by two levels of thiamin or niacin in comparison of control, however the feed intake as TDN, DCP and DE did not significantly affected by the supplements.

\section{Body weight gain:}

Results of growth performance as final body weight, total weight gain and daily gain are presented in Table (3). The values of total weight gain and daily gain were significant $(\mathrm{p}<0.05)$ higher in all tested rations in comparison with control that free from the experimental supplements. The differences among the tested rations was not significant, nevertheless the highest values were occurred with $\mathrm{T}_{4}$ that have the mix of the two supplements. This positive response of both supplements on growth performance could be attributed to the potentiality of medulatory effect of niacin and/or thiamin whose enhancing the most metabolic processes in the body. Pointedly and in support to these results, McDowell (2000) demonstrated that thiamin is adding to ruminants' rations containing high level of concentrate on the basis that may have an important role as a coenzyme for the certain enzymes in Krebs cycle and pentose pathway, so, thiamin is necessary for carbohydrates metabolism. Earlier, Dawson (1994) reported that yeast culture are rich source of vitamins, enzymes and others important nutrients and act as cofactor which make them attractive as digestive enhancers of basic source of nutrients. Results of growthfattening performance in the present study are closely similar to those reported by Flachowsky (1993) who indicated that beef cattle appeared to be beneficial as niacin supplemented at $1 \mathrm{~g} / \mathrm{h} / \mathrm{d}$ or about $100 \mathrm{mg} / \mathrm{kg}$ DMI, when body weight of bulls is lower than $300 \mathrm{~kg}$ and diets are poor in protein content (10 to $12 \%$ ) of DM and during dietary adaptation period.

On other work, influence of added niacin $(0.0,0.5$ or $1.00 \mathrm{~g} / \mathrm{h} / \mathrm{d})$ and $\mathrm{CP}$ content $(9.2$ to $12.0 \%)$ of DM or supply of different $\mathrm{N}$-source (urea, rapeseed meal, soya bean or fish meal) were investigated respecting rumen fermentation, feed intake and weight gain with growing bull weighing 175-300 kg. Niacin increased weight gain with urea $(43 \mathrm{~g} / \mathrm{h} / \mathrm{d})$ and with rapeseed or soy-rations $(60 \mathrm{gm} / \mathrm{h} / \mathrm{d})$, but did not influence with fish meal-ration. Increasing weight gain resulted from ruminal and metabolic effects (about 2/3) as well as enhanced feed intake of bulls (1/3) as revealed by Flachowsky et al. ( 1993). Regarding thiamin supplementation, El-Shanti et al. (2012) found similar effect in which 20 or $40 \mathrm{mg} / \mathrm{h} / \mathrm{d}$ incorporated in diets of lambs, being both levels enhanced growth performance, however, the highest value was found with low level. Also, Kholif et al. (2013) found similar results with ewes, where 40 $\mathrm{mg} / \mathrm{h} / \mathrm{d}$ thiamin supplementation into their ration led to an increase in their milk yield. Earlier study proved that when diet of feedlot steer was supplemented by $0.190 \mathrm{mg}$ thiamin $/ \mathrm{kg}$ diet, the daily gain was significantly $(\mathrm{p}<0.05)$ higher $(104 \mathrm{~kg} / \mathrm{d})$ compared with control $(0.92 \mathrm{~kg} / \mathrm{d})$ (Grigat and Mathison, 1982).

Regarding feed conversion that expressed as $\mathrm{kg}$ DM, TDN and DCP per kg gain, it could be observed that significant $(\mathrm{p}<0.05)$ improvement due to both supplements and its mixture were found respecting DM, TDN or DCP : gain (Table 3). Results here are in agreement with those obtained by El-Shanti et al. (2012) who recorded that feed conversion being 5.87, 4.99 and $5.16 \mathrm{~kg}$ feed per kg gain for zero, 20 or 40 $\mathrm{mg}$ thiamin/h/d with Assaf lambs. In conclusion, results reviewed in literature suggested a possible role of thiamin and niacin supplementations when dietary contents of NDF and ADF are lower and NFC is higher than recommended (Shaver and Bal, 2000). Considerable further studies are needed to quantify to what extent thiamin/niacin supplementation to the high energy diet of beef cattle would be effect on fermentation pattern in rumen, metabolic processes and feed conversion. 
Table (3): Average feed intake, body weight gain (kg) and feed conversion for fattening buffalo calves fed the experimental rations.

\begin{tabular}{|c|c|c|c|c|c|}
\hline \multirow{2}{*}{ Item } & \multicolumn{4}{|c|}{ Experimental rations } & \multirow[t]{2}{*}{$\pm \mathrm{SE}$} \\
\hline & $\mathrm{T} 1$ & $\mathrm{~T} 2$ & T3 & $\mathrm{T} 4$ & \\
\hline Number of animals & 5 & 5 & 5 & 5 & \\
\hline Experimental period (days) & 120 & 120 & 120 & 120 & \\
\hline \multicolumn{6}{|l|}{ Feed intake ( $\mathrm{kg} / \mathrm{head} /$ day) as fed: } \\
\hline Concentrate feed mixture (CFM) & 7.25 & 7.31 & 7.31 & 7.39 & \\
\hline Corn Silage (CS) & 3.62 & 3.66 & 3.66 & 3.69 & \\
\hline Rice Straw (RS) & 1.81 & 1.83 & 1.83 & 1.85 & \\
\hline Feed additives (gm) & ---- & 0.5 & 0.5 & $0.25+0.25$ & \\
\hline \multicolumn{6}{|l|}{$\begin{array}{l}\text { Feed intake (kg/head/day) on DM } \\
\text { basis: }\end{array}$} \\
\hline CFM & 6.61 & 6.68 & 6.68 & 6.74 & \\
\hline $\mathrm{CS}$ & 0.98 & 0.99 & 0.99 & 1.00 & \\
\hline RS & 1.70 & 1.72 & 1.72 & 1.74 & \\
\hline \multicolumn{6}{|l|}{ Total intake $(\mathrm{kg})$ as: } \\
\hline DM intake (kg/day) & 9.29 & 9.39 & 9.39 & 9.48 & \\
\hline TDN intake (kg/day) & 6.00 & 6.25 & 6.17 & 6.62 & \\
\hline DCP intake (kg/day) & 0.81 & 0.85 & 0.84 & 0.87 & \\
\hline $\mathrm{DE}$ (Mcal/kgDMI) & 0.26 & 0.28 & 0.27 & 0.29 & \\
\hline \multicolumn{6}{|l|}{ Live body weight, $\mathrm{kg}$ : } \\
\hline Initial weight & 277.6 & 275.0 & 275.8 & 276.6 & $9.20^{*}$ \\
\hline Final weight & $367.2^{\mathrm{b}}$ & $394.0^{\mathrm{ab}}$ & $391.4^{\mathrm{ab}}$ & $398.2^{\mathrm{a}}$ & 9.09 \\
\hline Total live weight gain & $89.6^{\mathrm{b}}$ & $119.0^{\mathrm{a}}$ & $115.6^{\mathrm{a}}$ & $121.6^{\mathrm{a}}$ & 6.42 \\
\hline Daily gain $(\mathrm{gm})$ & $747^{\mathrm{b}}$ & $992^{\mathrm{a}}$ & $963^{\mathrm{a}}$ & $1013^{a}$ & 0.05 \\
\hline \multicolumn{6}{|l|}{ Feed Conversion : } \\
\hline $\mathrm{kg}$ DM intake / kg gain & $12.46^{\mathrm{a}}$ & $9.47^{\mathrm{b}}$ & $9.74^{\mathrm{b}}$ & $9.36^{\mathrm{b}}$ & 0.23 \\
\hline $\mathrm{kg}$ TDN intake / kg gain & $8.04^{\mathrm{a}}$ & $6.30^{\mathrm{b}}$ & $6.40^{\mathrm{b}}$ & $6.54^{\mathrm{b}}$ & 0.35 \\
\hline $\mathrm{kg}$ DCP intake / kg gain & $1.09^{\mathrm{a}}$ & $0.86^{\mathrm{b}}$ & $0.87^{\mathrm{b}}$ & $0.85^{\mathrm{b}}$ & 0.02 \\
\hline
\end{tabular}

\section{Blood parameters:}

Data of some blood parameters for experimental dietary treatments are presented in Table (4). Concentration of total protein did not significant affected by all tested treatments in comparison with control one. Results here are supported by the findings of Kholif et al. (2009) who found non significant differences due to added different levels of thiamin into dairy cows' rations respecting blood total protein concentration. Also, blood creatinine concentration was comparable with all dietary treatments. Otherwise, urea concentration was significant $(\mathrm{p}<0.05)$ decrease by either niacin or its mixture with thiamin compared with control, and vice versa with thiamin supplement. Concerning liver enzymes, most of AST value were non significant affect by treatments, except that of $T_{3}$ (thiamin supplement) having the highest one $(\mathrm{p}<0.05)$. However, ALT activity was significant $(\mathrm{p}<0.05)$ decreased with all supplements compared with control that have the highest value.

In contrary, Mostafa et al. (2015) indicated that total protein content in blood was significant increased with supplementation of different levels of either niacin or thiamin with fattening Friesian calves. While the values of each creatinine, AST and ALT were not significantly affected by these supplements. Earlier, Mehrez et al. (2004) concluded that yeast culture (as a good source of vit B complex) supplementation to growing sheep diets has a positive effects on their productive performance without any adverse effect on blood constituents and in more specific had higher impact when supplemented with high concentrate diet than roughage one. 
Table (4): Some blood parameters of fattening buffalo calves fed experimental rations.

\begin{tabular}{lccccc}
\hline & \multicolumn{3}{c}{ Experimental rations } & \multirow{2}{*}{ \pm SE } \\
\cline { 2 - 5 } Item & $\mathrm{T} 1$ & $\mathrm{~T} 2$ & $\mathrm{~T} 3$ & $\mathrm{~T} 4$ & \\
\hline T. protein $(\mathrm{g} / \mathrm{dl})$ & 7.67 & 8.44 & 7.88 & 8.81 & $0.36^{*}$ \\
Urea (g/dl) & $3.81^{\mathrm{a}}$ & $2.89^{\mathrm{b}}$ & $3.97^{\mathrm{a}}$ & $2.71^{\mathrm{b}}$ & 0.24 \\
Creatinine (mg/dl) & 1.71 & 1.99 & 1.71 & 1.97 & $0.09^{*}$ \\
AST (IU/L) & $34.77^{\mathrm{b}}$ & $34.69^{\mathrm{b}}$ & $36.19^{\mathrm{a}}$ & $34.69^{\mathrm{b}}$ & 0.28 \\
ALT (IU/L) & $15.17^{\mathrm{a}}$ & $13.15^{\mathrm{d}}$ & $14.40^{\mathrm{b}}$ & $13.85^{\mathrm{c}}$ & 0.15 \\
\hline a, $b$, c and : Means in the same rows with different superscripts are significantly different at $(P<0.05) . * N \cdot S=$ non \\
significant
\end{tabular}

\section{Economical efficiency:}

Economical evaluation data of the dietary experimental treatments are presented in Table (5). Results of the present study demonstrate that feed cost per kg live weight gain was markedly deceased with for

Table (5): Economical evaluation of fattening buffalo calves fed experimental rations.

\begin{tabular}{|c|c|c|c|c|}
\hline \multirow[b]{2}{*}{ Item } & \multicolumn{4}{|c|}{ Experimental rations } \\
\hline & $\mathrm{T} 1$ & $\mathrm{~T} 2$ & $\mathrm{~T} 3$ & $\mathrm{~T} 4$ \\
\hline \multicolumn{5}{|l|}{ Feed intake (kg/head/day) as fed: } \\
\hline Concentrate feed mixture (CFM) & 7.25 & 7.31 & 7.31 & 7.39 \\
\hline Corn Silage & 3.62 & 3.66 & 3.66 & 3.69 \\
\hline Rice Straw & 1.81 & 1.83 & 1.83 & 1.85 \\
\hline \multicolumn{5}{|l|}{ Feed additives } \\
\hline Average daily gain $(\mathrm{kg})$ & 0.75 & 0.99 & 0.96 & 1.01 \\
\hline \multicolumn{5}{|l|}{ Economic evaluation: } \\
\hline Gain price (LE /day) & 26.13 & 34.71 & 33.72 & 35.47 \\
\hline \multicolumn{5}{|l|}{ Feed Cost (LE/head/day): } \\
\hline Concentrate Intake & 20.29 & 20.48 & 20.47 & 20.68 \\
\hline Corn silage intake & 1.45 & 1.46 & 1.46 & 1.48 \\
\hline Rice Straw intake & 0.54 & 0.55 & 0.55 & 0.55 \\
\hline Price of additive (LE) & 0.00 & 0.04 & 0.09 & 0.07 \\
\hline Total feed cost (LE/day) & 22.29 & 22.53 & 22.57 & 22.77 \\
\hline Feed cost / kg gain & 29.84 & 22.72 & 23.43 & 22.47 \\
\hline Net revenue(LE/head/day) ${ }^{\mathrm{A}}$ & 3.85 & 12.18 & 11.14 & 12.69 \\
\hline Increasing rates of revenue $(\%)$ & 100 & 316 & 289 & 329 \\
\hline Economic efficiency ${ }^{\mathrm{B}}$ & 1.17 & 1.54 & 1.49 & 1.56 \\
\hline Improvement of economic efficiency (\%) & 100 & 131 & 127 & 133 \\
\hline
\end{tabular}

Price of feedstuffs and supplementation : 2800 LE/Ton of concentrate feed mixture (CFM) and 400 LE/Ton of corn silage, $300 \mathrm{LE} / \mathrm{ton}$ Rice straw, $180 \mathrm{LE} / \mathrm{kg}$ of Thiamin, $80 \mathrm{LE} / \mathrm{kg}$ of Niacin, and price of live body weight: $35 \mathrm{LE} / \mathrm{kg}$ live body weight.

${ }^{A}$ Net revenue $($ LE/head/day $)=$ money output - money input

${ }^{B}$ Economic efficiency $=$ money output/money in put

tested rations compared with control one. Also, the net revenue (LE/h/d) was markedly increased with all supplemented rations compared with control one, with the highest value was associated with the mixture 
supplement (thiamin and niacin). Similar trend was observed in economic efficiency among dietary treatments. The improvement of economical efficiency values being 100,131, 127 and $133 \%$ for $\mathrm{T}_{1}, \mathrm{~T}_{2}$, $\mathrm{T}_{3}$ and $\mathrm{T}_{4}$, respectively. Results obtained by this study are in agreement with those obtained by Kholif et al. (2009) who worked with dairy cows and using thiamin supplement, El-Shanti et al. (2012) who used lambs with thiamin supplement, Mehrez et al. (2013) who tested live yeast supplement (good source of Vit. B complex) on grown lambs performance and lastly Mostafa et al. (2015) who worked with Friesian calves with different levels of either niacin or thiamin supplements. Generally, the modern livestock feeding programs are actually using a huge kinds of feed additives for enhancement feed and economic efficiencies especially in very intensive feeding systems. It is potentially have an added value for farm economic efficiency whenever properly used.

\section{CONCLUSION}

Conclusively this study could be emphasized on the very important role of each niacin and/or thiamin supplementation into the diets of ruminants particularly at finishing phase of fattening calves, where the concentrate feed mixture represent high percentage in their rations. Results proved that either niacin or thiamin and its mixture had an effectiveness role for improving the performance of fattening buffalo calves.

\section{REFERENCES}

A.O.A.C. (1995). Official Methods of analysis, $16^{\text {th }}$ Ed., Association of Official Analytical Chemists, Washington, DC, USA.

Bartels, H. (1971). A colorimetric method for creatinine estimation. J. Clin. Chem. Acta., $32: 81$.

Carro, M.D. and E.L. Miller (1999). Effect of supplementing a fiber basal diet with different nitrogen forms on ruminal fermentation and microbial growth in an In-vitro semi-continuous culture system (RUSITEC). British J. of Nutr., 82:149-157.

Dawson, K.A. (1994). Current and future role of yeast culture in animal production. A review of research over the last six years. Proc, Alltech's $8^{\text {th }}$ Ann. Symp. (suppl), Alltech, Tech. Puhl. Kentucky, USA, P1.

Doreau. M. and J.F. Ottou (1996). Influence of niacin supplementation on In-vivo digestibility and ruminal digestion in dairy cows. J. Dairy. Sci., 79:2247-2254.

Doumas, B. (1971). Colorimetric determination of albumin. Clin. Chem. Acta, 31: 87.

Duncan, D.B., (1955). Multiple range and Multiple F. test, Biometrics, 11:1.

El-Shanti, H.A.; A.M. Kholif; M.A. Hanafy; K.J. Al-Shakkrit and I.M. El- Hasaynah (2012). Effect of thiamin supplementation to diet on the productive performance of lambs. Egypt, J. Nutr. and Feeds, 15 (1): Especial Issue, 67-80.

Erasmus, L.J.; P.M. Botha and A. Kistner (1992). Effect of yeast culture supplement on production, rumen fermentation and duodenal nitrogen flow in dairy cows. J. Dairy Sci., 75: 3056-3065.

Flachowsky, G. (1993). Niacin in dairy and beef cattle nutrition. Arch. Anim. Nutr. 43:195 - 213.

Flachowsky, G. D. Wolfarm, H. Wilk and M. Schneider (1993). The influence of oral niacin doses during different dietary protein levels on indexes of rumen fermentation, blood prarameters and fattening performance of young bulls. Arch Tierernahr, 45 (2): 111-129, Germany.

Gabr, A. A.; A.Z. Mehrez; M.Y. El-Ayek; M.R.M. Mostafa and E. Kh. Hamed (2004). Influence of dry yeast cultur (Lacture) supplementation to sheep diets differing in roughage:concentration ratio on nutrient digestibilities, feeding values and some rumen parameters. $7^{\text {th }}$ Vet. Med. Zag. Conf. (21-23 July), Sharm El - Sheikh. 
Girard, C. L. (1998). B-complex vitamins for dairy cows - a new approach. Canadian J. Anim. Sci. 78 (Suppl.) : 71- 90.

Girard, C.L.; J. Chiquette and J.J. Matte (1994). Concentrations of folates in ruminal content of steers : response to dietary supplement of folic acid in relation with the nature of the diet. J. Anim. Sci. 72:1023-1028.

Grigat, G.A. and G.W. Mathison (1982). Thiamin supplementation of an all- concentrate diets for feedlot steers. Canad. J. Anim. Sci., 62:807-819.

Harmeyer, J. and U. Kallenkirchen (1985). Thiamin and niacin in ruminant nutrition. Nutr. Rev., 2:201225.

Hungate, R.E. (1966). The rumen and its microbes, Acad. Press, New York and Lodon.

Kamalamma, U. Kirshnamoorthy and P. Krishnappa (1996). Effect of feeding yeast culture (Yea - Sacc 1026) on rumen fermentation in vitro and production performance in crossbred dairy cow. Anim. Feed Sci. Techno. 57:247-256.

Kearl, L.C. (1982). Nutrient requirements of ruminants in developing countries. International feedstuffs Institute, Utah. Agric. Expt. Stat. Utah State Univ. USA.

Kholif, A.M.; H.A. Hamdon and G.M.A. Solouma (2013). Effect of supplementing ration with thiamin on milk yield and composition in Sohagi sheep. $14^{\text {th }}$ Sci. Conf. Of Anim. Nutri., Nov., Hurgada, Egypt.

Kholif, A.M., M.A. Hanafy; Ahlam A. El - Shewy; M.H. Abdel Gawad and Eman S.A. Farahat (2009). Effect of supplementing rations with thiamin and /or sodium bicarbonate on milk yield and composition of lactating cows. Egypt, J. Nutr., Feeds 12 (2) : 187-195

Kumar, R.D. and R.S. Dass (2005). Effect of niacin supplementation on rumen metabolites in Murrah buffaloes (Bubalus bubalis). Asian-Austral J. Anim. Sci., 18(1) : 38-41.

McDowell, L.R. (2000). Vitamins in animal and human nutrition. $2^{\text {nd }}$ Ed. Iowa state Univ. Press Ames, USA. PP. 265.

Mehrez, A.Z.; A.A. Gabr; M.Y. El-Ayek; M.R.M. Mustafa and E.Kh. Hamed (2004). Growth performance of growing lambs fed diets differing in concentrate:roughage ratio and supplemented with a probiotic. Egypt, J. Anim. Prod. Supp. Issue (41) : 267-274.

Mehrez, A.Z.; A.A. Gabr; A.A. Mahrous; O.A. Zelak and Amal M.A. Fayed (2013). Influence of live yeast feed additives on productive performance of growing Rahmany lambs. J. Anim. and poul. Prod. Mansoura Univ., vol 4 (5) : 233-247.

Miller, E.L. (2002). Protein source for the animal feed industry. Proc., Expert consul. and workshop, Bangkok, 29 April-3 May, FAO, Anim. and Health, pp.29.

Mostafa, M. R. M.; Ebtehag I. M. Abou - Elenin; A. A. Abdou ; and W. A. Riad (2015). Effect of thiamin or niacin supplementation into the rations of growing fattening calves on their productive performance. Egypt. J. Nutur and Feeds, 18 (3); 373- 382.

Nocek, J.E. and J.B. Russell (1988). Protein and energy as an integrated system. Relationship of ruminal protein and carbohydrate availability to microbial synthesis and milk production. J. Dairy Sci., 71:2070-2107.

NRC, (1988). Nutrient Requirements of Dairy Cattle.6th Rev. Ed., National Research Council Acad. Sci., Washington, DC, USA.

Ottou, J.F. and M. Doreau (1996). Influence of niacin on In-vitro ruminal fermentation and microbial synthesis depending upon dietary factors. Anim. Feed Sci., Technol. 58:187-199.

Peters, T. (1968). Determination of blood total protein. Clin., Chem. $14: 1147$.

R.C.F.F. (2001). Tables of chemical composition for animal and poultry feeds. Regional Center for Food and Feeds, ARC, Ministry of Agriculture, Egypt, Bull. No. 1, 2001

Reitman, S. and S. Frankel (1957). Colorimetric methods for the determination of serum glutamic oxaloacetic and glutamic - Pyruvate transminases. Am. J. Clin., Pathol., 28:56.

SAS (1999). SAS Procedure Guide. Version 6.12 Edition. SAS Institute Inc.,Cary,NC, USA. 
Solouma, G.M.A.; H.A. Hamdon and A.M. Kholif (2013). Effect of thiamin supplementation in ration on milk yield, composition and some blood components of sohagi sheep. Egypt, J. Nutr. Feeds 16 (1) : 17-25.

Santschi, D.E.; J. Chiquette; R. Berthiaume; R. Martineau; R. Matte; A.F. Mustafa and C.L. Girard (2005). Effect of the forage to concentrate ratio on - vitamins concentrations in different ruminal functions of dairy cows. J. of Anim. Sci., 85 (3): 289-399.

Schwab, E.C.; C.G. Schwab, R.D.D. Shaver; C.L. Grard; D.E. Putnam and N.L. Whitehouse (2006). Dietray forage and non fiber carbohydrate content influence B- vitamin intake, duodenal flow and apperant ruminal synthesis in lactating dairy cows. J. Dairy Sci. 89:174-187.

Shaver, R.D. and M.A. Bal (2000). Effect of dietary thiamine supplementation on milk production by dairy cows. J. Dairy Sci., 83 (10) : 2335-2340.

Shields, D.R.; D.M. Schaefer and T.W. Ferry (1983). Influence of niacin supplementation and nitrogen sources on rumen microbial fermentation. J. Anim. Sci., 57:1576-1583.

Snedecor, G.W. and W.G. Cochran (1980). Statistical Methods. $5^{\text {th }}$ Ed. Iowa State, Univ. Press, Ames, Iowa USA. 313 p.

Van Keulen, J. and B.A. Young (1977). Evaluation of acid -insoluble Ash as a natural marker in ruminant digestibility studies. J. Anim. Sci., 44 : 282 - 287.

Wang, Z.; M.L. Eastride and X. Qui (2001). Effects of forage neutral detergent fiber and yeast culture on performance of cows during early lactation. J. Dairy Sci., 84 : 204-212.

Zinn, R.A.; F.N. Owen; R.L. Stuart; J.R. Dundar; B.B. Norman (1987). B-vitamin supplementation of diets for feedlot calves. J. Anim. Sci., 65: 267-277. 
تأثير الإضافات الغذائية لكل من النياسين و/أو الثيامين على أداء النمو والتسمين للعجول الجاموسى

إبتهاج إبراهيم حمحم أبو العنين ،على أحمد عبده على ، واصف عبد العزيز رياض و محمد رفاعي محمود مصطفى

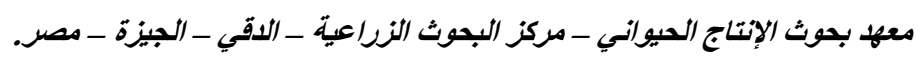

أجريت هذه الدراسة لتقبيم تأثثر إضافة كل من الثيامين والنياسين (من مجموعة فيتامين ب) أو مخلوطهما على أداء النمو و التسمين

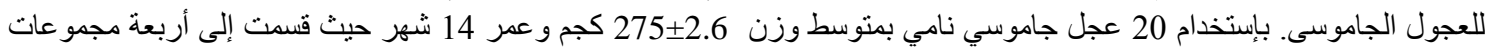

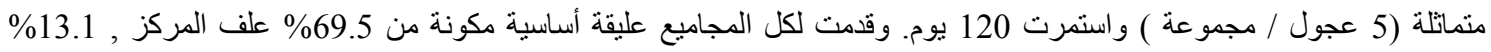

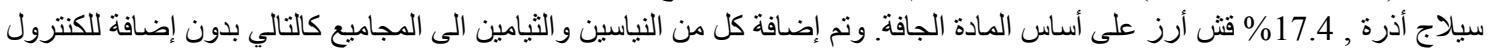

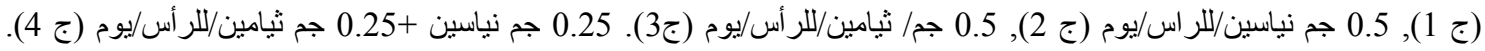

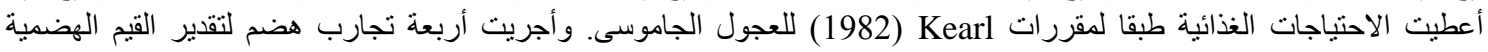

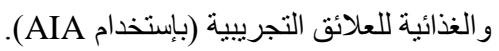

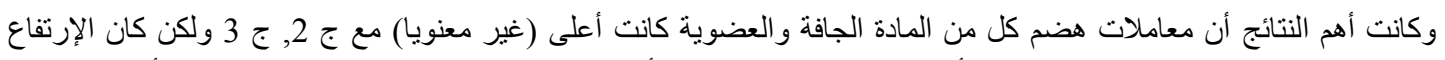

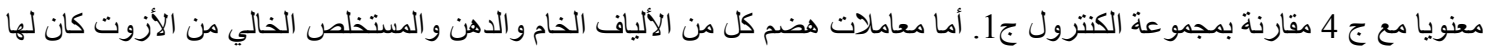

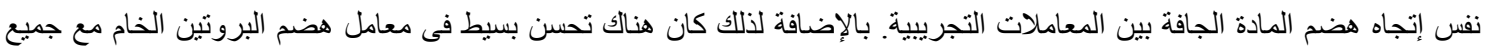

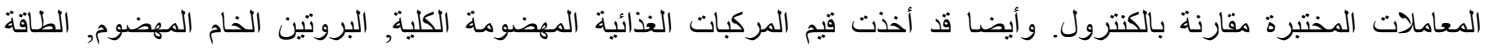

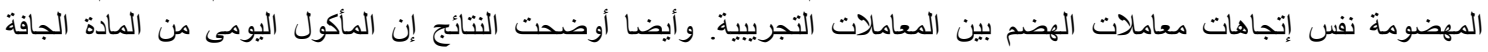

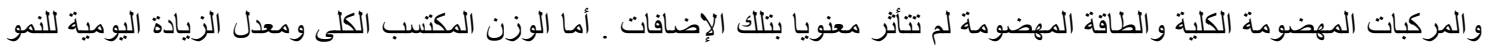

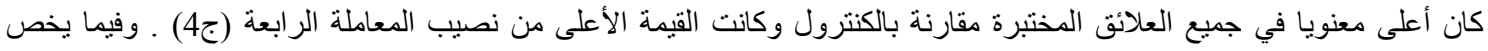

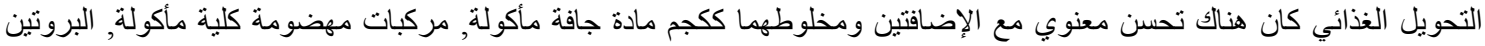

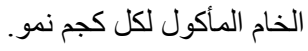

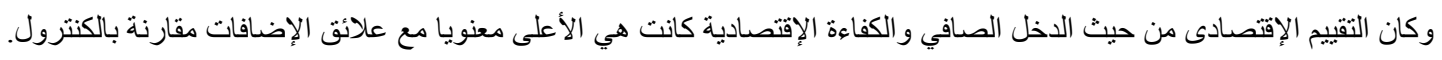

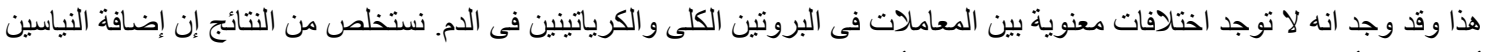
أو الثيامين أو مخلوطهما كان لهان لهم دور هام فى تحسين أداء العجول الجاموسى المسمنة عند ارتفاع نسبة المو اد المركزة فى العليقة. 